\title{
The laparoscopic management of Swyer syndrome: Case series
}

\author{
Neena Malhotra, Vatsla Dadhwal, Kandala Aparna Sharma, Deepika Gupta, Sumita Agarwal, Dipika Deka \\ Department of Obstetrics and Gynecology, All India Institute of Medical Sciences, New Delhi, India
}

\begin{abstract}
Swyer syndrome, also known as $46 \mathrm{XY}$ pure gonadal dysgenesis, is a rare endocrine disorder. Affected individuals are phenotypically female with female genitalia, normal Mullerian structures, absent testicular tissue, and a $46 \mathrm{XY}$ chromosomal constitution.

We report a series of eight cases of Swyer syndrome, of which six were managed by laparoscopic gonadectomy. The two other cases had to undergo an exploratory laparotomy in view of their presentation with adnexal masses. Two of the girls were siblings. The chief presenting complaint was primary amenorrhea. Four girls also presented with a history of poor development of secondary sexual characters. The average age at presentation was $16.19 \pm 2.85$ years. The average height was $158.33 \pm 4.63 \mathrm{~cm}$, and the average weight was $49.33 \pm 8.44 \mathrm{~kg}$. Breast development was either Tanner 2 or 3 in four girls, whereas three girls had a Tanner 1 underdeveloped breasts. Axillary and pelvic hair was sparse in all the girls. The vagina was well canalized in all the girls. Hormonal evaluation revealed hypergonadotropic hypogonadism with a mean follicle-stimulating hormone (FSH) level of $95.81 \mathrm{mIU} / \mathrm{L}$ and a mean luteinizing (LH) level of $24.15 \mathrm{mIU} / \mathrm{L}$. Imaging analysis revealed the presence of a small uterus in all the cases, except one. Bilateral ovaries were either not visualized or streak gonads were present. Adnexal mass was detected in two of the six cases with raised carcinoembryonic antigen (CA) 125 levels in one case. Genetic analysis revealed a karyotype of $46 \mathrm{XY}$ in six girls, $46 \mathrm{XY} / 45 \mathrm{X}$ in one, and the culture repeatedly failed in one girl. Because of the risk of malignancy, bilateral gonadectomy was performed in all cases. Histopathological analysis revealed that three of the six cases had dysgerminoma. The patients have been started on hormone replacement therapy. Laparoscopy is a minimally invasive modality for the definitive diagnosis and treatment of cases with Swyer syndrome. An early diagnosis of Swyer syndrome is possible during workup for primary amenorrhea before they present with adnexal masses. (J Turk Ger Gynecol Assoc 2015; 16: 252-6)
\end{abstract}

Keywords: Swyer syndrome, laparoscopic gonadectomy, gonadoblastoma

Received: 20 April, $2015 \quad$ Accepted: 23 August, $2015 \quad$ Available Online Date: 02 November, 2015

\section{Introduction}

Swyer syndrome is a condition characterized by the presence of an unambiguously female phenotype and Mullerian structures in the presence of a " $\mathrm{y}$ " line (XY karyotype), as was first described by Jim Swyer in 1955. The Swyer syndrome XY female should be differentiated from the other conditions of the XY female, such as testicular feminization, because they have different implications on the current management and future reproductive function. Over a period of 2 years, we managed eight cases of Swyer syndrome, of which, five patients were managed by laparoscopic bilateral gonadectomy.

Laparoscopy provides a minimally invasive approach for the management of these cases if detected at an appropriate time.

\section{Case Series}

Over a period of 2 years, eight young patients with Swyer syndrome were diagnosed and treated.

An informed consent was taken for case review and reporting. All the cases presented to the outpatient department with complaints of primary amenorrhea, and four patients also presented with a history of poor development of secondary sexual characters.
The average age at presentation was $16.19 \pm 2.85$ years. The average height was $158.33 \pm 4.63 \mathrm{~cm}$, and the average weight was $49.33 \pm 8.44 \mathrm{~kg}$. Breast development was either Tanner 2 or 3 in 4 cases, whereas three cases had a Tanner 1 underdeveloped breasts. Axillary and pelvic hair was sparse in all the patients.

On abdominal examination, one of the patients had a $5 \times 4 \mathrm{~cm}$ palpable mass in the lower abdomen, whereas the rest had no significant abdominal findings.

On vaginal examination, the vagina was well canalized in all cases, and the uterus could not be palpated. Two of the cases had palpable adnexal masses, of which, one had bilateral adnexal masses $(7 \times 5 \mathrm{~cm}$ right and $5 \times 5 \mathrm{~cm}$ left adnexa), whereas the others had a fixed mass in the pelvis.

A hormonal analysis was performed in all the cases, and it revealed a hypergonadotropic state, confirming gonadal dysgenesis, which is a feature of the Swyer syndrome.

Ultrasound examination revealed a small uterus with nonvisualization of ovaries in all the cases.

Out of the eight patients, six had a $46 \mathrm{XY}$ karyotype. One patient had a mosaic [45 X (40\%); 46 XY (60\%)] karyotype, and the culture for karyotype failed twice in one of the patients but was included in the series because the clinical presentation was strongly suggestive. 


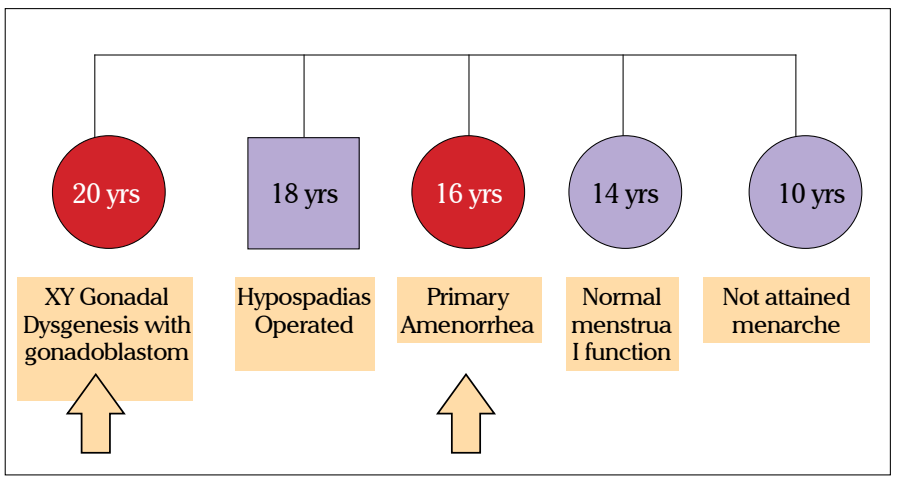

Figure 1. The pedigree chart of familial Swyer syndrome siblings

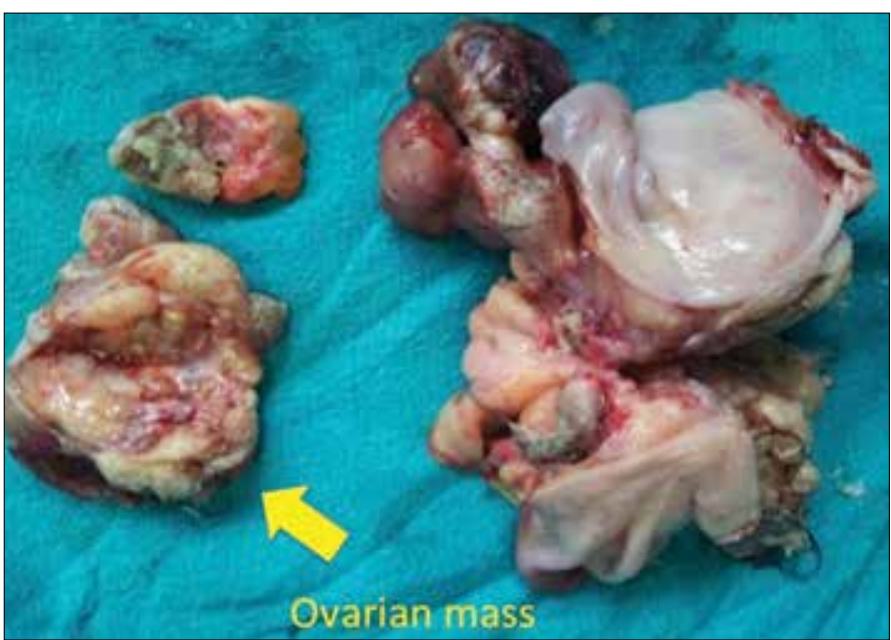

Figure 2. Tumor deposit on the uterus with a $6 \times 5 \mathrm{~cm}$ right ovarian mass in one of the young girls with Swyer syndrome presenting with an adnexal mass

Out of these cases, two were siblings who had a familial Swyer syndrome, whereas the rest of them were sporadic occurrences (Figure 1). One of the two siblings of familial Swyer syndrome had a history of laparotomy and left salpingotomy of an ovarian tumor at the age of 11 years. A review of the records revealed it to be dysgerminoma stage 1a.

The principals of management included laparoscopic gonadectomy, appropriate management of adnexal masses in the specific cases, followed by hormone replacement therapy (HRT).

Five out of the eight cases underwent laparoscopic gonadectomy. All of them had streak gonads. In one of the patients who had previously undergone left oophorectomy for a dysgerminoma, the right streak gonad also revealed a dysgerminoma on histopathological examination.

Exploratory laparotomy with ascitic fluid cytology with total abdominal hysterectomy and bilateral salpingo-oophorectomy $(\mathrm{TAH}+\mathrm{BSO})$ with infracolic omentectomy was performed in one of the cases with bilateral adnexal masses and raised carcinoembryonic antigen (CA 125) and lactate dehydrogenase (LDH) levels. Intraoperatively, there was a $6 \times 4 \mathrm{~cm}$ tumor deposit on the uterus with a $6 \times 5 \mathrm{~cm}$ right ovarian mass (Figure 2 ). On the left side, there was a streak gonad. Bilateral tubes and omentum were unremarkable. Histopathological examination revealed a dysgerminoma in the right ovary.
The other patient with an adnexal mass also underwent an exploratory laparotomy with bilateral gonadectomy along with the removal of the rudimentary uterus, tubes, and infracolic omentectomy. The gonadal mass was also histopathologically characterized as dysgerminoma (Figure 3).

The clinical presentation and management of the six cases with non-familial Swyer syndrome has been summarized in Table 1, 2 and those of familial Swyer syndrome siblings has been summarized in Table 3, 4.

All the patients were put on HRT post-surgery. The two young cases with adnexal masses were registered in a cancer clinic, and they are under follow up.

\section{Discussion}

Swyer syndrome, $46 \mathrm{XY}$ complete gonadal dysgenesis, is an uncommon entity occurring in a ratio of 1: 80,000 in the general population (1). In our case series, we managed five out of the eight cases with laparoscopic surgery. Laparoscopy provides a minimally invasive approach for the management of these cases if detected on time before they present with germ cell tumors. Michala et al. (1) reported a case series of 29 women with Swyer syndrome. The method of gonadectomy has not been specified in that series. However, because the period of study included even those diagnosed before 1990s, laparoscopy as a method of management might not have been uniformly available. In the current perspective, however, the role of laparoscopy cannot be overemphasized.

The age at diagnosis is an important determinant in the management of Swyer syndrome because of the risk of gonadal malignancy, initiation of adequate HRT for the induction of puberty, and for the improvement of bone mineral density. The average age at diagnosis in our series was 19.8 years compared with 17.2 years in the series by Michala et al. (1).

The diagnosis of Swyer syndrome is made around the time of puberty when the child who has been reared as a female fails to achieve menarche and has delayed development of secondary sexual characters. In our series, all the cases had primary amenorrhea, and 4 out of the 8 cases also had a delayed development of secondary sexual characters. Two of the young cases also had adnexal masses at the time of diagnosis. The presence of adnexal masses precludes a laparoscopic management as laparotomy with staging would be warranted.

The characteristic feature that differentiates Swyer syndrome from another disorder of XY females such as androgen insensitivity syndrome (AIS) is the higher propensity for malignant transformation. In Swyer syndrome, both internal and external genitalia are female, and there is hypergonadotropic hypogonadism, whereas in AIS, the external genitalia are female, internal are male, and they have hypogonadotropic hypogonadism. In our series of eight patients, two had presented with ovarian masses with amenorrhea, and the histopathology revealed dysgerminoma. In the series of 29 cases, $1.32 \%$ had dysgerminoma and $14 \%$ had gonadoblastoma. Han et al. (2) described a case of dysgerminoma diagnosed in a dysgenetic gonad of a 21-yearold patient with Swyer syndrome, who presented with primary 


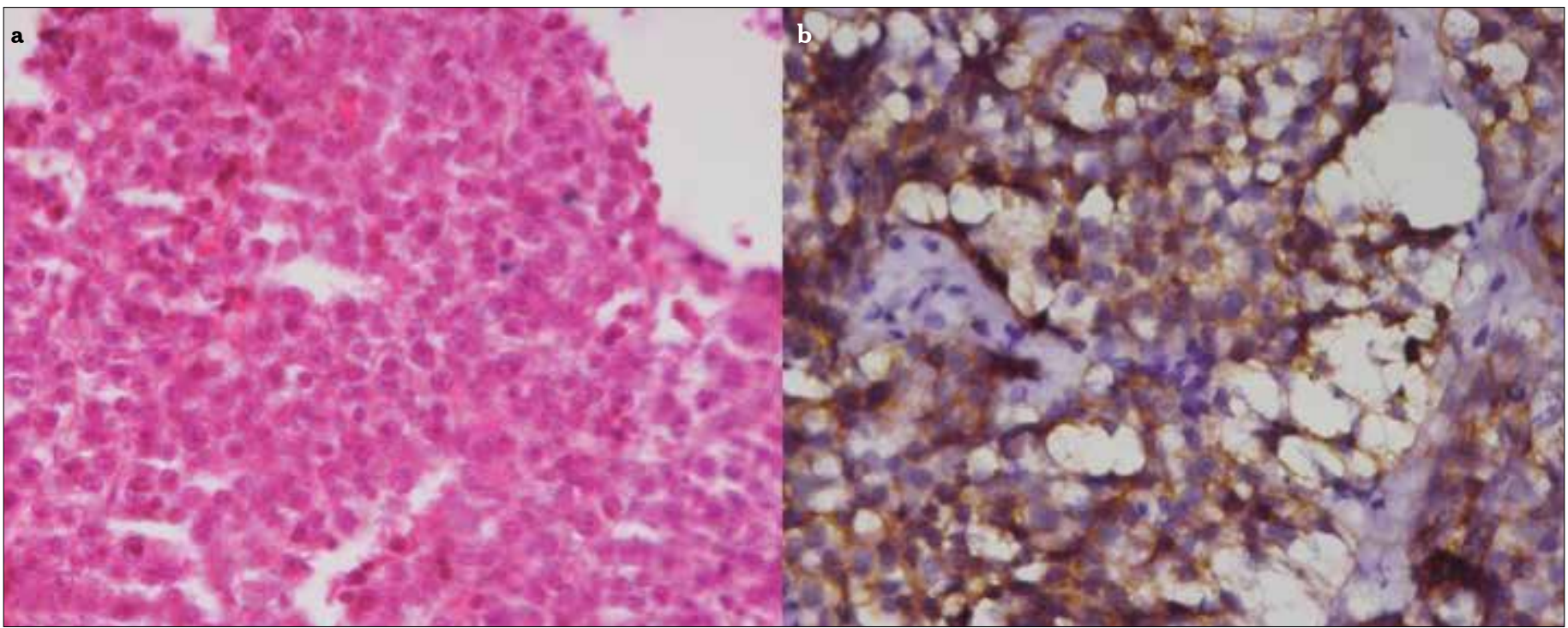

Figure 3. a, b. Microphotograph showing dysgerminoma cells (a) which were immunopositive for placental alkaline phosphatase (PLAP), (b)

Table 1. Summary of patients with Swyer syndrome (non-familial)

\begin{tabular}{|c|c|c|c|c|c|c|}
\hline Sr. no. & 1 & 2 & 3 & 4 & 5 & 6 \\
\hline \multicolumn{7}{|l|}{ Clinical Findings } \\
\hline Age (years) & 22 & 19 & 24 & 18 & 8 & 17 \\
\hline Chief Complaint & $\begin{array}{l}\text { Primary } \\
\text { amenorrhea }\end{array}$ & $\begin{array}{l}\text { Primary } \\
\text { amenorrhea }\end{array}$ & $\begin{array}{l}\text { Primary } \\
\text { amenorrhea } \\
\text { with abdominal } \\
\text { pain and } \\
\text { infertility }\end{array}$ & $\begin{array}{l}\text { Primary } \\
\text { amenorrhea } \\
\text { with poor } \\
\text { secondary } \\
\text { sexual } \\
\text { characters }\end{array}$ & $\begin{array}{l}\text { Lump } \\
\text { abdomen } \\
\text { (presented at } 14 \\
\text { years again with } \\
\text { primary } \\
\text { amenorrhea and } \\
\text { poor secondary } \\
\text { sexual characters }\end{array}$ & $\begin{array}{l}\text { Primary } \\
\text { amenorrhea } \\
\text { with poor } \\
\text { secondary } \\
\text { sexual } \\
\text { characters }\end{array}$ \\
\hline Height $(\mathrm{cm})$ & 158 & 165 & 154 & 155 & NA & 138 \\
\hline Weight (kg) & 53 & 60 & 50 & 54 & NA & 38 \\
\hline Breast (Tanner) & 2 & 3 & 3 & 1 & Not developed & 1 \\
\hline Axillary/Pubic Hair & Sparse & Sparse & Sparse & Sparse & Not developed & absent \\
\hline $\begin{array}{l}\text { Abdominal } \\
\text { Examination }\end{array}$ & Soft & Soft & $\begin{array}{l}5 \times 4 \mathrm{~cm} \text { palpable } \\
\text { mass in the lower } \\
\text { abdomen }\end{array}$ & Soft & $\begin{array}{l}6 \times 6 \text { mass felt per } \\
\text { abdomen }\end{array}$ & Soft \\
\hline $\begin{array}{l}\text { Vaginal } \\
\text { Examination }\end{array}$ & $\begin{array}{l}\text { Vagina well } \\
\text { canalized }\end{array}$ & $\begin{array}{l}\text { Vagina well } \\
\text { canalized }\end{array}$ & $\begin{array}{l}\text { Uterus anteverted } \\
\text { Normal sized } \\
7 \times 5 \mathrm{~cm} \text {, right } \\
\text { adnexal mass, } \\
5 \times 5 \mathrm{~cm}\end{array}$ & $\begin{array}{l}\text { Vagina well } \\
\text { canalized }\end{array}$ & $\begin{array}{l}\text { Vagina well } \\
\text { canalized }\end{array}$ & $\begin{array}{l}\text { Vagina well } \\
\text { canalized }\end{array}$ \\
\hline $\begin{array}{l}\text { Rectal } \\
\text { Examination }\end{array}$ & $\begin{array}{l}\text { Uterus not } \\
\text { felt }\end{array}$ & $\begin{array}{l}\text { Uterus not } \\
\text { felt }\end{array}$ & $\begin{array}{l}\text { No nodularity, } \\
\text { rectal mucosa } \\
\text { free }\end{array}$ & Uterus not felt & $\begin{array}{l}\text { No nodularity, } \\
\text { rectal mucosa free }\end{array}$ & Uterus not felt \\
\hline
\end{tabular}

amenorrhea and infertility for a duration of 5 years. Karyotype was consistent with $46 \mathrm{XY}$ (pure). Behtash et al. (3) reported the development of dysgerminoma in three phenotypic female patients with $46 \mathrm{XY}$ pure gonadal dysgenesis. All patients presented first with abdominopelvic mass. The youngest case of gonadoblastoma has been reported in a 9-month-old girl with ambiguous genitalia (4). Maleki et al. (5) reported a case of gonadoblastoma and dysgerminoma diagnosed on touch preparation in a dysgenetic gonad of a 16-year-old patient with Swyer syndrome. 
Table 2. Investigations and management summary (non-familial)

\begin{tabular}{|c|c|c|c|c|c|c|}
\hline Sr. no. & 1 & 2 & 3 & 4 & 5 & 6 \\
\hline $\mathrm{LH}(\mathrm{mIU} / \mathrm{L})$ & 90.19 & 86.6 & 26.1 & 30.2 & & 28.3 \\
\hline $\mathrm{FSH}(\mathrm{mIU} / \mathrm{L})$ & 14.4 & 22.4 & 107.1 & 99.7 & Raised & 52.87 \\
\hline CA125 (IU/L) & & & 159.5 & & & \\
\hline $\mathrm{AFP}(\mathrm{IU} / \mathrm{L})$ & & & 2.2 .4 & & & \\
\hline $\mathrm{HCG}(\mathrm{mIU} / \mathrm{L})$ & & & 5.88 & & & \\
\hline LDH (U/L) & & & 1673 & & Raised & \\
\hline Imaging & $\begin{array}{l}\text { Uterus small } \\
\text { bilateral } \\
\text { ovaries not } \\
\text { seen }\end{array}$ & $\begin{array}{l}\text { Uterus small } \\
\text { bilateral } \\
\text { ovaries not } \\
\text { seen }\end{array}$ & $\begin{array}{l}\text { Uterus small. } \\
14.5 \times 6.4 \times 10.3 \mathrm{~cm} \\
\text { solid, } \\
\text { multilobulated } \\
\text { mass, ascites } \\
\text { present. Bilateral } \\
\text { ovaries not seen } \\
\text { separately }\end{array}$ & $\begin{array}{l}\text { Uterus } \\
4.7 \times 6.4 \times 10.3 \mathrm{~cm} \text {. } \\
\text { Left ovary not } \\
\text { seen. } 1.2 \times 0.6 \mathrm{~cm} \\
\text { linear structure in } \\
\text { the right broad } \\
\text { ligament }\end{array}$ & $\begin{array}{l}\text { Bilateral solid } \\
\text { ovarian masses } \\
\text { with a rudimentary } \\
\text { uterus }\end{array}$ & $\begin{array}{l}\text { Uterus small } \\
\text { bilateral } \\
\text { ovaries not } \\
\text { seen }\end{array}$ \\
\hline Karyotype & $46 \mathrm{XY}$ & $46 \mathrm{XY}$ & $46 \mathrm{XY}$ & $46 \mathrm{XY}$ & Culture failed twice & $\begin{array}{l}45 \mathrm{X}(40 \%) / \\
46 \mathrm{XY}(60 \%)\end{array}$ \\
\hline Surgery & $\begin{array}{l}\text { Laparoscopic } \\
\text { gonadectomy }\end{array}$ & $\begin{array}{l}\text { Laparoscopic } \\
\text { gonadectomy }\end{array}$ & $\begin{array}{l}\text { Exploratory } \\
\text { laparotomy with } \\
\text { ascitic fluid } \\
\text { cytology with total } \\
\text { abdominal } \\
\text { hysterectomy with } \\
\text { infracolic } \\
\text { omentectomy }\end{array}$ & $\begin{array}{l}\text { Laparoscopic } \\
\text { right } \\
\text { gonadectomy }\end{array}$ & $\begin{array}{l}\text { Exploratory } \\
\text { laparotomy with } \\
\text { bilateral } \\
\text { gonadectomy }\end{array}$ & $\begin{array}{l}\text { Laparoscopic } \\
\text { right } \\
\text { gonadectomy }\end{array}$ \\
\hline Histopathology & Streak gonads & Streak gonads & Dysgerminoma & Dysgerminoma & Dysgerminoma & Streak gonads \\
\hline
\end{tabular}

Table 3. Summary of the clinical findings of familial Swyer syndrome siblings

\begin{tabular}{|l|l|l|}
\hline Sr. no. & $\mathbf{1}$ & $\mathbf{2}$ \\
\hline Clinical findings & \multicolumn{2}{|l|}{} \\
\hline Age (years) & 16 & 20 \\
\hline Chief complaint & Primary amenorrhea & $\begin{array}{l}\text { Primary amenorrhea with poor secondary } \\
\text { sexual characters }\end{array}$ \\
\hline Height $(\mathrm{cm})$ & 155 & 163 \\
\hline Weight $(\mathrm{Kg})$ & 37 & 42 \\
\hline Breast (Tanner) & 2 & 1 \\
\hline Axillary/pubic hair & Sparse & Sparse \\
\hline Abdominal examination & Soft & Soft \\
\hline Vaginal examination & Vagina well canalized & Vagina well canalized \\
\hline Rectal examination & Uterus not felt & Fixed mass felt anteriorly \\
\hline
\end{tabular}

Because of the dysgenetic gonads, the risk of gonadoblastoma and dysgerminoma has been estimated to be between $15 \%$ and $35 \%$, and it is advisable to perform bilateral gonadectomy as soon as the diagnosis is made. This is in contrast with the management in another XY disorder such as AIS or true hermaphroditism that have a lower malignant potential.

Swyer syndrome is characterized by the presence of female internal organs. In most cases, the uterus is small and non- functional. Similar to our series of eight patients, seven had small dimensional uteri, but one of them had a uterine length of $4 \mathrm{~cm}$. Apart from the imaging modalities, direct visualization under laparoscopy also aids in assessing the uterine size and its appropriateness for future reproductive function. In the case series of 29 patients (1), 8 patients had an ultrasound (US) assessment of uterine length, which was found to have a median length of $62 \mathrm{~mm}(48-82 \mathrm{~mm})$. Three out of 
Table 4. Investigations and management summary of familial Swyer syndrome siblings

\begin{tabular}{|c|c|c|}
\hline Sr. no. & 1 & 2 \\
\hline LH (mIU/L) & 29.84 & 22 \\
\hline FSH (mIU/L) & 102.3 & 89 \\
\hline CA 125 (IU/L) & & 7.9 \\
\hline $\begin{array}{l}\text { AFP (IU/L) } \\
\text { HCG (mIU/L) }\end{array}$ & & 1.08 \\
\hline $\mathrm{LDH}(\mathrm{U} / \mathrm{L})$ & & 1.66 \\
\hline Imaging & $\begin{array}{l}\text { Uterus not seen, bilateral } \\
\text { streak gonads }\end{array}$ & $\begin{array}{l}\text { Small uterus, } 7 \times 5 \mathrm{~cm} \text { right adnexal solid } \\
\text { cystic mass }\end{array}$ \\
\hline Karyotype & $46 \mathrm{XY}$ & $46 \mathrm{XY}$ \\
\hline Surgery & Laparoscopic gonadectomy & $\begin{array}{l}\text { Exploratory laparotomy and peritoneal wash cytology } \\
\text { with bilateral gonadectomy with bilateral salpingectomy } \\
\text { and infracolic omentectomy }\end{array}$ \\
\hline Histopathology & Streak gonads & Left streak gonad, right dysgerminoma \\
\hline
\end{tabular}

these had achieved successful pregnancies following ovum donation.

Swyer syndrome can occur in families, as found in the two siblings in our series. Generally, the diagnosis of Swyer syndrome in one member prompts a screening of other siblings for the presence of primary amenorrhea with or without poor development of secondary sexual characteristics. In our series, one of the siblings first underwent a laparotomy because she presented with an ovarian mass. However, on pedigree analysis, one of her siblings was also diagnosed with Swyer syndrome, and she underwent a laparoscopic gonadectomy. In a report by Kempe et al. (6), an asymptomatic woman (age, 38 years) with a family history of ovarian malignancies was referred for pre-symptomatic genetic testing of mutations in the BRCA genes. The family history revealed three affected paternal aunts. Two of them developed ovarian malignancies at 13 and 15 years of age and died at 19 and 20 years of age. This disease was diagnosed in the third aunt ( 82 years old) at the age of 35 years. Bagci et al. (7) have reported two siblings with Swyer syndrome along with the same history in their mother's maternal aunt who was subsequently diagnosed to have XY cell lines. Anecdotal case reports of families with XY Gonadal Dysgenesis (GD) have been described (8). The modes of transmission described in these families include autosomal recessive, autosomal dominant with a variable penetrance, and X-linked pattern of inheritance. This case series highlights the role of laparoscopy in the diagnosis and management of Swyer syndrome. Early diagnosis, a minimally invasive approach to gonadectomy, followed by HRT and family screening are the cornerstones of the management of this rare disorder. Menstrual function and pregnancy can be achieved in a select group of patients.

Ethics Committee Approval: N/A.

Informed Consent: Written informed consent was obtained from patients who participated in this case.
Peer-review: Externally peer-reviewed.

Author Contributions: Concept - N.M., V.D., D.D., A.S.; Design - A.S., V.D., S.A.; Supervision - N.M., V.D.; Materials - A.S., D.G., S.A.; Data Collection and/or Processing - A.S., S.A., D.G.; Analysis and/or Interpretation - A.S., V.D., S.A.; Literature Search - A.S., S.A., D.G.; Writing - A.S., S.A., V.D.; Critical Reviews - N.M., V.D., D.D.

Conflict of Interest: No conflict of interest was declared by the authors.

Financial Disclosure: The authors declared that this study has received no financial support.

\section{References}

1. Michala L, Goswami D, Creighton S, Conway G. Swyer syndrome: presentation and outcomes. BJOG 2008; 115: 737-41. [CrossRef]

2. Han Y, Wang Y, Li Q, Dai S, He A, Wang E. Dysgerminoma in a case of 46, XY pure gonadal dysgenesis (Swyer syndrome): a case report. Diagn Pathol 2011; 6: 84. [CrossRef]

3. Behtash N, Zarchi M K. Dysgerminoma in three patients with Swyer syndrome. World J Surg Oncol 2007; 5: 71. [CrossRef]

4. Dumic M, Jukic S, Batinica S, Ille J, Filipovic-Grcic B. Bilateral gonado- blastoma in a 9-month-old infant with $46, \mathrm{XY}$ gonadal dysgenesis. J Endocrinol Invest 1993; 16: 291-3. [CrossRef]

5. Maleki Z, Loveless M, Fraig M. Coexistence of gonadoblastoma and dysgerminoma in a dysgenetic gonad on touch preparation: a case report. Diagn Cytopathol 2011; 39: 42-4. [CrossRef]

6. Kempe A, Engels H, Schubert R, Meindl A, van der Ven K, Plath $\mathrm{H}$, et al. Familial ovarian dysgerminomas (Swyer syndrome) in females associated with 46 XY-karyotype. Gynecol Endocrinol 2002; 16: 107-11. [CrossRef]

7. Bagci G, Bisgin A, Karauzum SB, Trak B, Luleci G. Complete gonadal dysgenesis 46,XY (Swyer syndrome) in two sisters and their mother's maternal aunt with a female phenotype. Fertil Steril 2011; 95: 1786e1-e3.

8. Sarafoglou K, Ostrer H. Clinical review 111: familial sex reversal: a review. J Clin Endocrinol Metab 2000; 85: 483-93. [CrossRef] 